\title{
Historian suuria linjoja
}

\section{Teppo Eskelinen}

Immanuel Wallerstein, Randall Collins, Michael Mann, Georgi Derluguian \& Craig Calhoun: Onko kapitalismilla tulevaisuutta? Gaudeamus \& Vastapaino 2014. Alkuteos Does Capitalism Have a Future? Oxford University Press 2013.

Taloustieteen heikkous pitkän aikavälin tulevaisuuden kuvailussa on silmiinpistävää, vaikka tulevaisuuden odotukset tuntuvatkin muodostavan talousjärjestelmän ytimen. Vielä Keynesille oli mahdollista ja järkevää kirjoittaa lastenlasten taloudellisesta tulevaisuudesta. Nykyisin kysymys pitkän aikavälin taloudellisesta tulevaisuudesta tuntuu lähinnä kiusalliselta: siitä ei oikein voi puhua. Abstrakti markkina-aika ei tavoita tulevaisuusskenaarioiden ydintä, eikä taloustiede pysty oikein ottamaan kantaa talousinstituutioiden jatkuvuuteen tai talousinstituutioiden yhteiskunnalliseen asemaan, eli suuriin linjoihin.

Samaan aikaan elämme suurta kriisien aikakautta. Kaikki tuntuvat olevan yhtä mieltä siitä että kriisi on käynnissä, vaikkei kukaan osaakaan sanoa, minkä kriisistä on oikeastaan kyse. Tässä ilmapiirissä on tavallaan helpompikin esittää kysymyksiä talousjärjestelmän perustasta ja tulevaisuudesta, kunhan siirrytään taloustieteellisestä otteesta sosiologiseen.

Äskeittäin ilmestynyt Onko kapitalismilla tulevaisuutta? on vahva analyysi taloudellisesta tulevaisuudesta. Viisi raskaan sarjan makrososiologia on kerääntynyt yhteen pohtimaan järjestelmän elinehtoja, aikahorisonttina suurin piirtein kuluva vuosisata. Immanuel Wallerstein, Randall Collins, Michael Mann, Georgi Derluguian ja Craig Calhoun ovat riittävän yksimielisiä kirjoittaakseen yhdessä kirjan ja riittävän erimielisiä rakentaakseen kirjaan pieniä sisäisiä jännitteitä. Yhteistä kirjoittajille on jonkinlainen sosiologisesti älykäs kriisitietoisuus, ja tausta pitkistä linjoista kiinnostuneina tutkijoina.

Kirjan asetelma on selvä: Wallerstein ja Collins ovat akateemisia tähtiä, tai vähintään jonkinlaisia referenssipisteitä. He paaluttavat suuret teoriansa kirjan alussa, ja muiden tehtäväksi jää lisätä niihin täydennyksiä, epäilyksiä ja varauksia. Se, että molemmat ennustivat aikoinaan reaalisosialismin tuhoutumisen hyvissä ajoin, muistetaan mainita moneen kertaan. Outoa 
kyllä, rakenne toimii. Wallersteinin ja Collinsin suuri kuva on kiinnostava, ja kirjan loppupuoli täydentää kertomusta sopivasti.

Kirjoittajien välinen kitka seuraa lähinnä kysymyksestä, onko kriisissä kapitalismi järjestelmänä vai jokin muu. Wallersteinin mukaan historian pitkiä syklejä analysoimalla voidaan todeta että kapitalismi muuttuu rakenteellisesti mahdottomaksi. Collinsin mukaan työn radikaali väheneminen ajaa kapitalismin järjestelmäkriisiin. Mann ja Calhoun viljelevät epäilyksiä siitä, saattaako ympäristökriisi ehtiä ennen kapitalismin järjestelmäkriisiä, ja voivatko kriisiyttävät tekijät tulevaisuudessakin seurata aivan muista kuin taloudellisista tekijöistä, kuten ydinaseiden leviämisestä. Tai ehkä kriisissä on pelkkä euro: yhden maanosan poliittinen typeryys siirtää globaalin hegemonian painopistettä. Derluguianin artikkeli taas kertoo hieman irrallisen tuntuisen vaikkakin erittäin kiinnostavan kertomuksen reaalisosialismista.

Wallerstein tulkitsee historiaa kahden sykliteorian pohjalta. Niin sanotut Kondratjeff-syklit ovat historian pitkiä, noin 50-70 vuoden mittaisia taloudellisia syklejä. Syklin ensimmäisessä vaiheessa kapitalistit pystyvät tekemään hyvin voittoa monopolivoiman ansiosta, jota tarjoavat tuotteiden uutuus sekä valtiovallan poliittinen tuki. Toisessa vaiheessa monopolivoima katoaa, ja alkaa talouden rakenteellinen stagnaatio ja finanssoituminen. Niin sanotut hegemoniasyklit merkitsevät taas yhden valtion tai valtakeskittymän kykyä sanella maailmantalouden "pelisääntöjä", tai tarkemmin tämän aseman nousua ja tuhoa. Wallersteinin analyysin ydin on, että maailmantalous on tällä hetkellä Kondratjeff-syklin laskuvaiheessa ja Yhdysvaltain hegemonian hallitseman hegemoniasyklin lopussa. Tämä tarkoittaa väistämättä, että parinkymmenen vuoden sisällä tilalle täytyy tulla ”jotain muuta": makrososiologin ennustus on, että nimenomaan kapitalismi on ajautumassa ratkaisevaan kriisiin.

Selvää on, että Wallerstein vetää mutkia suoriksi - kysymys kuuluukin, kuinka suoriksi. Mann esittää omassa tekstissään, että Kondratjeff-syklit ovat Wallersteinin esityksessä väärin ajoitettuja, ja pitää lisäksi hegemoniasykliteoriaa ongelmallisena: varhaiset imperialistiset voimavaltiot, kuten Alankomaat, eivät olleet hegemoneja lainkaan samassa mielessä kuin Yhdysvallat tänään.

Collinsille ydinkysymys on työn radikaali väheneminen ennen kaikkea teknologisen muutoksen johdosta. Työn loppuminen tuhoaa taloudelta kyvyn kasvaa ja tekee yhteiskunnat epästabiileiksi. Collinsin analyysi on hyvin erityylinen kuin Wallersteinilla mutta tuottaa saman johtopäätöksen: 
vallitsevat kehityskulut johtavat rakenteelliseen kriisiin, kun tunnetut taloudellisen ja poliittisen hallinnan muodot lakkaavat toimimasta.

Collinsin ennakoimaa "työn loppua" on toki ennustettu niin kauan kuin kapitalismia on ollut, ja aina jostain on tullut lisää palkkatyötä. Välttääkseen tällaisia helppoja ansoja Collins käy huolellisesti läpi "strategioita", joiden avulla historiassa on lisätty uutta työtä teknologisesti korvautuneen tilalle. Hänen pyrkimyksensä on osoittaa, ettei mikään näistä vanhoista strategioista toimi. Onkin totta, että muutos on dramaattista ja nopeaa: teollisuuskapitalismilta meni pari sataa vuotta automatisoida teollinen työ; nyt teknologia on korvaamassa monia "keskiluokkaisia töitä" muutaman kymmenen vuoden aikajänteellä. Collins kuitenkin niputtaa turhan helposti järjestelmän rakenteisiin liittyvät tekijät ja poliittiset kysymykset. Keynesiläinen strategia työn lisäämiseksi ei Collinsin mukaan toimi, koska sillä ei ole poliittista kannatusta - mutta eikö se tarkoita, ettei kysymys ole mistään ylittämättömästä tai rakenteellisesta esteestä?

Collins kehottaa kuvittelemaan yhteiskunnan, jossa rakenteellinen työttömyys on esimerkiksi 50 prosenttia. Pysyisikö sellainen yhteiskunta kasassa? Kirjoittaja tuntuu sanovan, että tämä merkitsisi käytännössä kapitalismin loppua. Toisaalta monissa nykyisissä kehitysmaissa virallinen työttömyysaste on korkeampikin, ja ihmiset selviävät erilaisten epävirallisten järjestelmien varassa - järjestelmä kestää kaikesta huolimatta. Ehkä myös uudet poliittiset strategiat voivat toimia vaikka työ vähenisikin radikaalisti, esimerkiksi pääomatulojen korkea verotus yhdistettynä korkeaan perustuloon.

Ydinasia on kuitenkin se, että kapitalismi on rakenne, jolla on rakenteellisia lainalaisuuksia. Selvää on myös, että kaikilla järjestelmillä on ikänsä riippumatta siitä, mitä mieltä on jonkin yksittäisen skenaarion perusteista. Jossain vaiheessa kapitalismi väistyy ja jotain muuta tulee tilalle. Toki kaikki kirjoittajat jaksavat myös muistuttaa, että tulevaisuudessa on paljon auki, makrososiologian malleissa on aina epätarkkuuksia, ja yksittäiset satunnaiset tekijät voivat muuttaa historian kulkua rajustikin. Myös kapitalismin määrittely on aito ongelma: Wallersteinin määritelmässä kapitalismi on jatkuvan pääoman kasaamisen järjestelmä, mutta voisi sen määritellä toisinkin.

Yhteiskuntatieteellisen ennakoinnin näkökulmasta keskeinen kysymys on, minkälaisia ituja tai vihjeitä kapitalismin jälkeisestä todellisuudesta nykyjärjestelmän rakenteissa voidaan nähdä. Wallerstein asettaa vastakkain 
"Davosin hengen" ja "Porto Alegren hengen": suuria vaihtoehtoisia linjoja ovat siis hierarkkinen ja horisontaalinen organisaatio. Tietenkään "henki" ei kerro institutionaalisista muodoista mitään, ja Wallerstein tietysti ymmärtää hyvin asetelmansa karkeuden.

Kiinnostavaa on myös Wallersteinin huomio "Davosin" jakaantuneisuudesta: nykyinen globaali eliitti on selvästi epävarma, kumpaan hallintastrategiaan sen pitäisi tarttua, kun valittavana on repressiivinen malli ja "pehmeämpi kapitalismi”. Ensimmäinen merkitsee tiukempaa kuria, joukkojenhallintaa ja häpeilemätöntä epädemokraattisuutta, eikä tarvitse lähteä yhtään Eurooppaa kauemmaksi nähdäkseen viitteitä tästä strategiasta. "Pehmeään kapitalismiin" taas kuuluu enemmän sääntelyä, tulonjakoa ja vihreitä investointeja.

Vaikka uskoisi kapitalismin romahdukseen, kysymys "romahduksen" luonteesta ja merkityksestä jää ilmaan. Olemme kyllästäneet mielikuvituksemme harhaanjohtavilla mielikuvilla: ympäristöromahdus on liian helppoa ajatella apokalypsin kuvaston kautta; ajatusta kapitalismin romahduksesta taas hallitsee klassinen vallankumouskuvasto. Kuitenkin historiallisesti siirtymät ovat yleensä olleet hitaita ja romahdukset pitkiä, todistajilleen harvoin äkkirysäyksiä vaan pikemmin kehkeytyviä havaintoja siitä, että olemassa olevat hallinnan mekanismit käyvät entistä toimimattomammiksi. Kapitalismin tai luonnonympäristön tai näiden alajärjestelmien romahdus voi kestää vuosikymmeniä. Ehkä romahdus on tällä hetkellä jo käynnissä, ja nykyinen Eurooppa vain todistaa, ettei kapitalismi-kansallisvaltio-järjestelmä enää selviä omilla hallinnan välineillään.

Kirjoittajien työstämä pitkä loppuluku palauttaa tekstin nykyhetkeen ja poliittisesti maan pinnalle. Käytyään pitkällisesti läpi samanmielisyyksiään ja erimielisyyksiään kirjoittajat keskittyvät vaatimaan poliittista suunnanmuutosta. Päätelmät ovat yksinkertaisia ja järkeenkäypiä: esimerkiksi eriarvoisuuden vähentäminen olisi keskeistä. Palattuaan maan pinnalle kirjoittajien visiot ovat kuitenkin huomattavasti latteampia kuin makrososiologian sfäärit. Systemaattista analyysia vallitsevasta talousjärjestelmästä osana historian suuria kehityskulkuja lukee niin harvoin, että nimenomaan suurten linjojen piirtelystä osaa nauttia vastapainona päivänpoliittiselle talousanalyysille. 